\title{
Hubungan Persepsi tentang Menopause dengan Kecemasan pada Wanita Premenopause
}

\author{
Ayunia Adha Henanda Putri , Ekorini Listiowati \\ Fakultas Kedokteran dan Ilmu Kesehatan Universitas Muhammadiyah Yogyakarta \\ Email: ekorini_santosa@yahoo.com
}

\begin{abstract}
ABSTRAK
Perubahan fisik dan psikologis pada wanita premenopause sering membuat mereka cemas. Dan kecemasan juga bisa menimbulkan gejala-gejala fisik. Gejala-gejala premenopause ini alami oleh banyak wanita hampir di seluruh dunia yaitu sekitar 70-80\% wanita Eropa, 60\% di Amerika dan 57\% di Malaysia, 18\% di Cina dan 10\% di Jepang dan Indonesia. Perubahan fisik dan psikologis ini juga dapat mempengaruhi kesejahteraan hidup dan kesehatan mental mereka.Penelitian ini adalah observational dengan metode analisis analitik dan dengan pendekatan cross sectional. Teknik pengambilan sampel dalam penelitian ini menggunakan Simple Random Sampling dengan 68 responden. Instrument penelitian untuk persepsi menggunakan quesionare persepsi tentang menopause dan untuk kecemasan menggunakan quesionare Hamilton Anxiety Rating Scale. Data yang diperoleh dianalisis dengan menggunakan tes korelasi, dan hasil perhitungan di dapatkan hasil korelasinya 0,296 dimana p>0,05, maka tidak ada hubungan yang signifikan. Hasil yang didapat antara persepsi dengan usia yaitu 0,002 sedangkan persepsi dengan pekerjaan diperoleh hasil 0,017. Hasil penelitian menunjukkan tidak ada hubungan yang signifikan antara persepsi tentang menopause dengan kecemasan pada wanita premenopause. Tetapi ada hubungan antara persepsi dengan usia dan pekerjaan sehingga bisa mempengaruhi hubungan dengan kecemasan.
\end{abstract}

Keywords: persepsi menopause, kecemasan, wanita premenopause

\begin{abstract}
Physical and psychological changes in premenopausal women often make them anxious. And anxiety can also cause physical symptoms. This premenopausal symptoms experienced by many women in almost all the world is about 70-80\% of women of Europe, 60\% in America and 57\% in Malaysia, 18\% in China and 10\% in Japan and Indonesia. Physical and psychological changes can also affect the well-being and mental health.This study is observational and analytic analysis method with cross sectional approach. The sampling technique in this study using the Simple Random Sampling with 68 respondents. Research instrument for use quesionare perception perception of menopause and for anxiety using quesionare Hamilton Anxiety Rating Scale.Data were analyzed using correlation tests, and the results of the correlation calculations get 0,296 results where p>0.05, there is no significant relationship. The results obtained between perception with age is 0.002 , while the perception of the results obtained 0,017 jobs. This study showed no significant relationship between the perception of menopause in premenopausal women with anxiety. But there is a relationship between age and job perceptions that could affect relations with anxiety.
\end{abstract}

Keywords: Perception menopause, anxiety, premenopause woman

\section{Pendahuluan}

Menopause terjadi secara alamiah dan pasti dialami oleh semua wanita. Menopause merupakan masa berhentinya siklus menstruasi dan hormonhormon kelamin wanita menghilang dengan cepat sampai hampir tidak ada (Guyton, 2008). Proses menopause ini akan membutuhkan waktu 3-5 tahun sampai benar-benar seorang wanita tersebut sudah berhenti haid selama 12 bulan. Setiap wanita akan mengalami masa menopause yang berbeda, pada umumnya terjadi pada usia 45-55 tahun (Mulyani, 2013).

Jika wanita menopause, akan ada faktorfaktor resiko yang akan dihadapi, di antaranya 
adalah osteoporosis, masalah urogenital, obesitas, penyakit kardovaskuler, diabetes dan lain-lain.

Sebelum wanita menginjak masa menopause, didahului dengan masa premenopause. Premenopause adalah masa transisi dari 2 sampai 10 tahun (alami selama 35-50 tahun) sebelum penghentian periode menstruasi secara utuh (Singh, 2006). Pada masa ini timbul perubahan fisiologis maupun psikologis akibat perubahan hormonal. Gejalanya seperti perbedaan waktu saat menstruasi, bisa lebih cepat atau lebih lama, rentang waktu dari menstruasi ke menstruasi berikutnya yang relatif lebih panjang dari biasanya, hot flushes, sulit tidur, kelelahan, gangguan pada pencernaan, kekeringan pada vagina, dan kehilangan konsentrasi. Adapun gejala psikis seperti perubahan pada emosi, misalnya menjadi mudah tersinggung, marah, murung, cemas, bingung, gelisah, pelupa dan lain-lain. Menurunnya kadar estrogen membuat wanita premenopause mengalami kecemasan. Rasa khawatir, gelisah, takut, tidak tentram dan sebagainya merupakan gejala-gejala dari cemas. Dan kecemasan juga bisa menimbulkan gejalagejala fisik. Gejala-gejala premenopause ini alami oleh banyak wanita hampir di seluruh dunia yaitu sekitar 70-80\% wanita Eropa, 60\% di Amerika dan $57 \%$ di Malaysia, $18 \%$ di Cina dan $10 \%$ di Jepang dan Indonesia (Proverawati, 2010). Perubahan fisik dan psikologis ini juga dapat mempengaruhi kesejahteraan hidup dan kesehatan mental mereka. Karena ada kemungkinan jika masalah ini dibiarkan tanpa mereka sadari bisa menjadi kasus mental di masa datang. Di Indonesia terutama di pedesaan biasanya masyarakat kurang memperhatikan diri tentang keluhan-keluhan yang berkaitan dengan menopause tersebut.

\section{Bahan dan Cara}

Penelitian ini adalah observational dengan metode analisis analitik dan dengan pendekatan cross sectional, yang menggambarkan variabel bebas yaitu persepsi tentang menopause dengan variabel terikat yaitu kecemasan pada wanita premenopause di Desa Brajan. Populasi yang digunakan dalam penelitian ini adalah semua wanita premenopause usia 40-55 tahun yang tercatat di Desa Brajan, Kecamatan Kasihan, Kabupaten Bantul yaitu sebanyak 209 orang.
Sampel yang diuji adalah 68 responden yang mendapat perlakuan yang sama yaitu dengan mengisi kuesioner dan wawancara dengan responden.

Sebagai kriteria inklusi adalah wanita premenopause usia 40-55 tahun, bersedia menjadi responden, mampu membaca dan menulis. Adapun wanita yang mengalami gangguan jiwa atau ada kelainan anatomis pada sistem reproduksinya seperti amenorhea primer dikeluarkan dari sampel penelitian.

Sebagai variabel bebas adalah persepsi terhadap menopause, sedangkan variabel tergantung adalah kecemasan pada wanita premenopause. Variabel bebas lainnya yaitu pendidikan,usia, depresi, panik, pengetahuan, pengalaman dan lingkungan.

Alat yang digunakan pada penelitian ini adalah kuesionerpersepsi tentang menopause diukur dengan kuesioner dengan skala likert yang dikelompokkan dalam pernyataan favorable (pernyataan yang mendukung) dan menggunakan kuesioner Hamilton Anxiety Rating Scale yang diisi oleh peneliti.

Penelitian telah dilakukan di Desa Brajan RT 1-10 pada bulan Juni sampai dengan November 2014.

Pelaksanaannya diawali dengan melakukan uji validitas dan reliabilitas pada 30 responden di Desa.... dilanjutkan dengan mengumpulkan data melalui observasi dengan melakukan wawancara dan mengisi kuesioner. Setelah data diperoleh dilakukan analisis data dengan metode statistik.

Analisa data menggunakan analisis univariat untuk menghitung distribusi frekuensi sehingga diketahui gambaran karakteristik responden. Uji dilanjutkan dengan analisis bivariat menggunakan chi-square untuk mengetahui hubungan antara persepsi tentang menopause dengan kecemasan pada wanita premenopause.

\section{Hasil dan Pembahasan}

Hasil penelitian dilakukan dengan menghitung distribusi frekuensi terhadap usia, tingkat pendidikan dan jenis pekerjaan yang diperlihatkan pada Tabel 1.

Pada Tabel 1. tampak bahwa sebagian besar responden berusia 40-44 tahun yaitu sebanyak 40 orang $(58,8 \%)$. Pekerjaan yang di miliki responden yang paling banyak diketahui berprofesi sebagai 
ibu rumah tangga atau tidak bekerja sebanyak 35 orang $(51,5 \%)$. Dari tingkat pendidikan yang

\begin{tabular}{lcc} 
Tidak sekolah & 6 & 8,8 \\
SD & 23 & 33,8 \\
SMP & 15 & 22,1 \\
SMA & 15 & 22,1 \\
Diploma & 3 & 4,4 \\
S1 & 5 & 7,4 \\
S2 & 1 & 1,5 \\
c. Jenis Pekerjaan & & \\
Wiraswasta & 7 & 10,3 \\
& & 51,5 \\
Ibu rumah tangga & 35 & 25 \\
Buruh & 17 & 7,3 \\
Tani & 5 & 5,9 \\
PNS & 4 & \\
\hline
\end{tabular}
paling banyak adalah tamatan SD yaitu sebanyak 23 orang $(33,8 \%)$.

Tabel 1. Karakteristik reponden berdasarkan usia, tingkat pendidikan dan jenis pekerjaan

\begin{tabular}{lcc}
\hline $\begin{array}{l}\text { Karakteristik } \\
\text { responden }\end{array}$ & Jumlah & Prosentase (\%) \\
\hline a. Usia & 40 & 58,8 \\
$40-44$ tahun & 20 & 29,4 \\
$45-49$ tahun & 8 & 11,8 \\
50-55 tahun & & \\
b. Pendidikan & &
\end{tabular}

Tabel 2. Distribusi frekuensi persepsi tentang menopause dengan kecemasan pada wanita premenopause

Persepsi * Kecemasan Crosstabulation

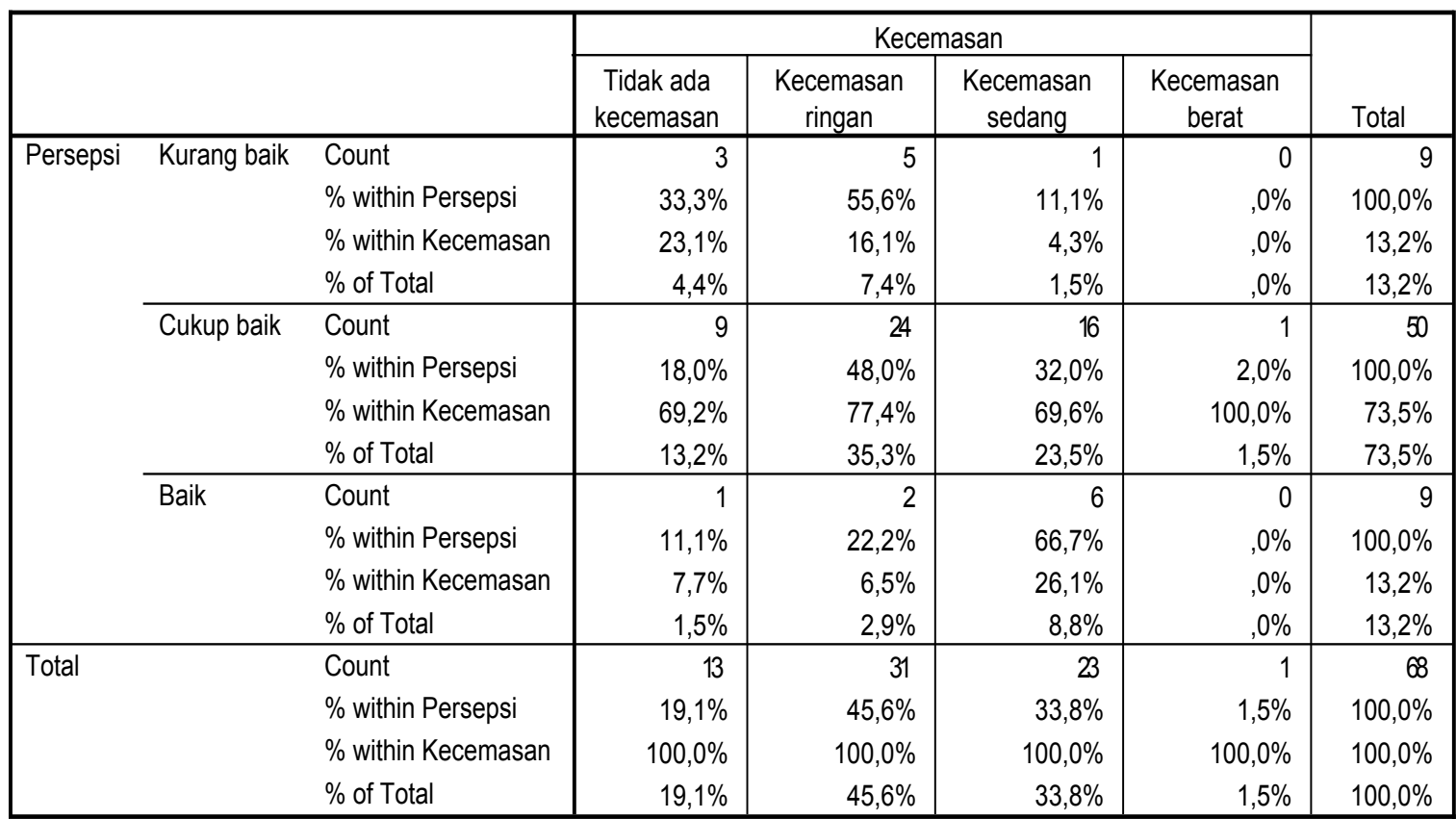

Tabel 3. Hasil analisis chi-square test hubungan antara persepsi tentang menopause dengan kecemasan terhadap wanita premenopause

\begin{tabular}{cc}
\hline $\begin{array}{c}\text { Hubungan persepsi - } \\
\text { kecemasan }\end{array}$ & $\mathrm{P}=0,269$ \\
\hline
\end{tabular}

Berdasarkan tabel 2. diatas diketahui dari 68 responden sebanyak 2 orang $(2,9 \%)$ memiliki persepsi baik dengan kecemasan rendah, 6 orang $(8,8 \%)$ memiliki persepsi baik dengan kecemasan sedang, 24 orang
$(35,3 \%)$ memiliki persepsi cukup baik dengan kecemasan rendah, 16 orang $(23,5 \%)$ memiliki persepsi cukup baik dengan kecemasan sedang.

Hasil penelitian yang di dapat kemudian dilakukan uji statistik dengan menggunakan uji chi-square dengan tingkat kepercayaan $95 \%$ atau taraf signifikan yaitu $\alpha=5 \%(\mathrm{p}<0,05)$ dan didapatkan nilai $\mathrm{P}=$ 0,296 sehingga dapat dinyatakan tidak ada hubungan yang bermakna antara persepsi 
dengan kecemasan pada wanita premenopause di Desa Brajan Kecamatan Kasihan, Kabupaten Bantul, Yogyakarta.

Tabel 4. Distribusi frekuensi persepsi-umur

Crosstab

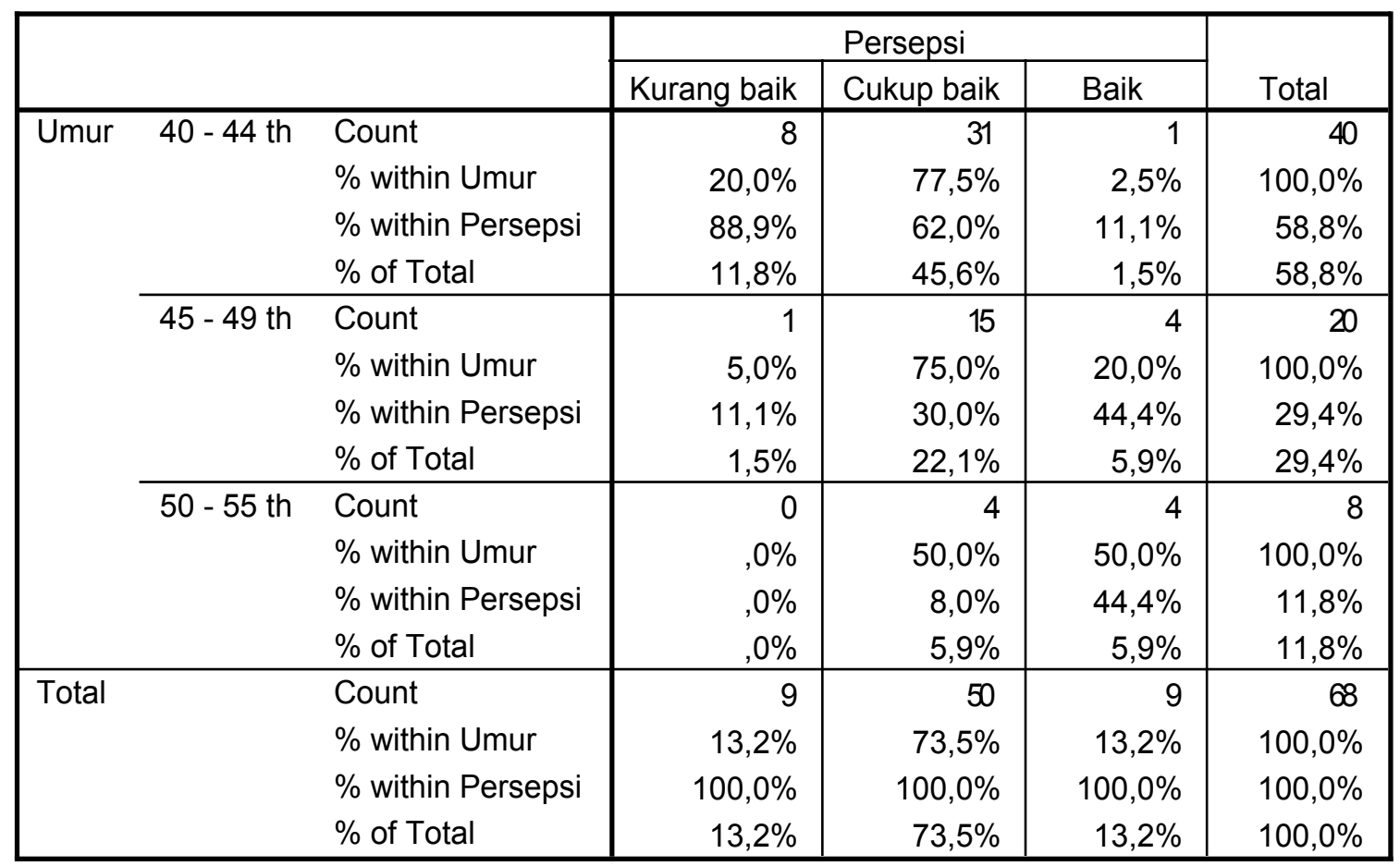

Tabel 5. Hasil analisis chi-square test hubungan antara persepsi tentang menopause dengan umur

Hubungan persepsi $\mathrm{P}=0,002$

- umur

Dari tabel 4. dapat diketahui hubungan persepsi dengan usia yang paling banyak adalah persepsi cukup baik dengan usia 40-44 tahun sebanyak 31 orang $(45,6 \%)$, persepsi cukup baik dengan usia 45-49 tahun sebanyak 15 orang (22,1\%). Dari hasil analisis dengan uji chi-square diketahui nilai $\mathrm{P}=0,002(\mathrm{P}<0,05)$, sehingga dapat dinyatakan ada hubungan antara persepsi dengan usia yang akan memasuki masa premenopause di Desa Brajan. 
Tabel 6. Distribusi frekuensi persepsi-pekerjaan

PEKERJAA * PERSEPSI Crosstabulation

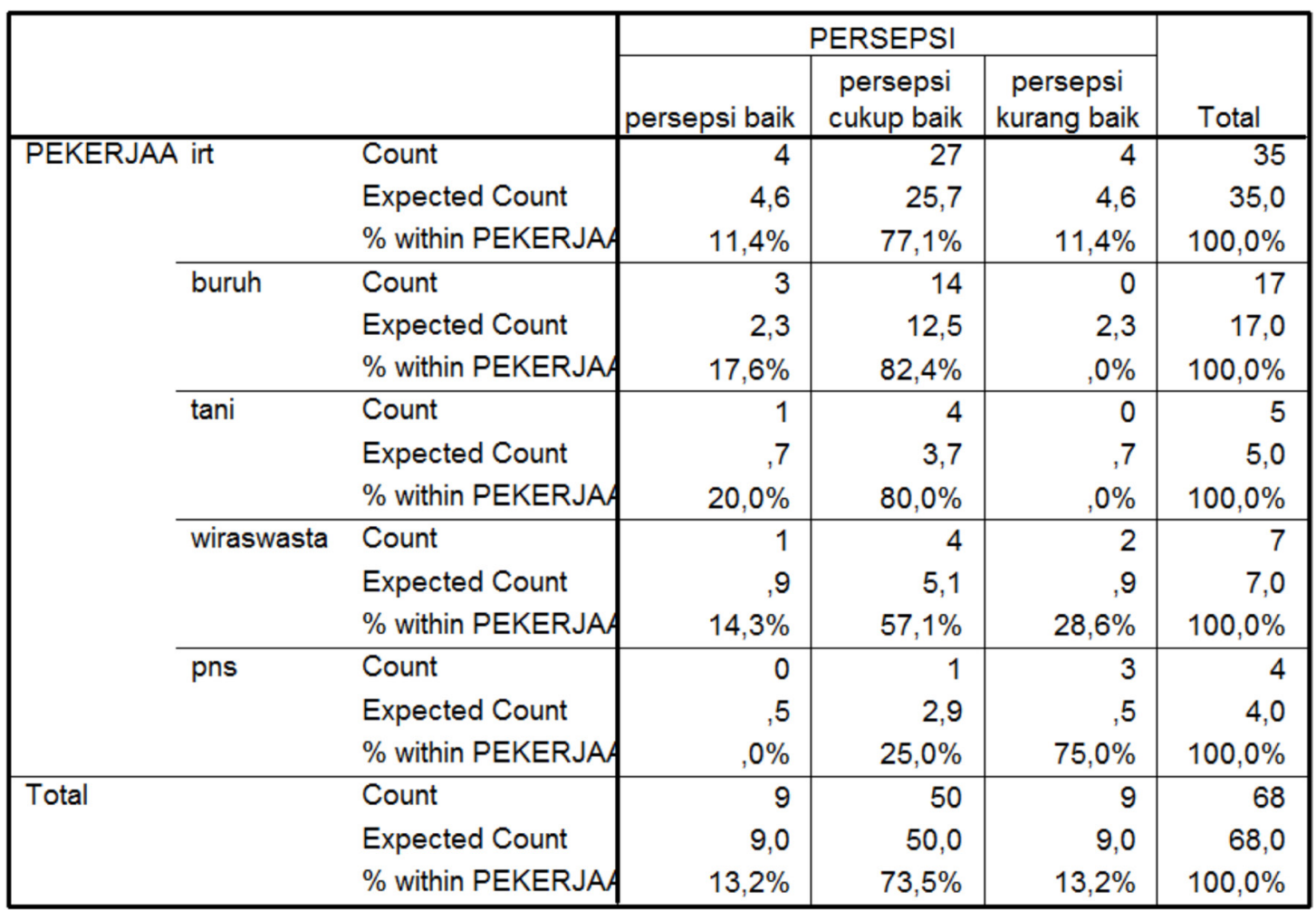

Tabel 7. Hasil analisis chi-square test hubungan antara persepsi tentang menopause dengan pekerjaan

\begin{tabular}{ll}
\hline Hubungan Persepsi-pekerjaan & $\mathrm{P}=0,017$ \\
\hline
\end{tabular}

Dari tabel 6. diketahui hubungan persepsi dengan pekerjaan yang paling banyak adalah persepsi cukup baik dengan pekerjaan sebagai ibu rumah tangga sebanyak 27 orang $(39,7 \%)$, kemudian persepsi cukup baik dengan pekerjaan sebagai buruh sebanyak 14 orang $(20,6 \%)$. Dari hasil analisis chi-square diketahui $\mathrm{P}=0,017(\mathrm{P}<$ $0,05)$, sehingga dapat dinyatakan ada hubungan antara persepsi dengan pekerjaan. 
Tabel 8. Distribusi frekuensi persepsi dengan pendidikan

Crosstab

\begin{tabular}{|c|c|c|c|c|c|c|}
\hline & & & \multicolumn{3}{|c|}{ Persepsi } & \multirow[b]{2}{*}{ Total } \\
\hline & & & Kurang baik & Cukup baik & Baik & \\
\hline \multirow[t]{28}{*}{ Pendidikan } & \multirow[t]{4}{*}{ Tidak sekolah } & Count & 1 & 3 & 2 & 6 \\
\hline & & $\%$ within Pendidikan & $16,7 \%$ & $50,0 \%$ & $33,3 \%$ & $100,0 \%$ \\
\hline & & $\%$ within Persepsi & $11,1 \%$ & $6,0 \%$ & $22,2 \%$ & $8,8 \%$ \\
\hline & & $\%$ of Total & $1,5 \%$ & $4,4 \%$ & $2,9 \%$ & $8,8 \%$ \\
\hline & \multirow[t]{4}{*}{$\mathrm{SD}$} & Count & 2 & 18 & 3 & 23 \\
\hline & & $\%$ within Pendidikan & $8,7 \%$ & $78,3 \%$ & $13,0 \%$ & $100,0 \%$ \\
\hline & & $\%$ within Persepsi & $22,2 \%$ & $36,0 \%$ & $33,3 \%$ & $33,8 \%$ \\
\hline & & $\%$ of Total & $2,9 \%$ & $26,5 \%$ & $4,4 \%$ & $33,8 \%$ \\
\hline & \multirow[t]{4}{*}{ SMP } & Count & 5 & 9 & 1 & 15 \\
\hline & & $\%$ within Pendidikan & $33,3 \%$ & $60,0 \%$ & $6,7 \%$ & $100,0 \%$ \\
\hline & & $\%$ within Persepsi & $55,6 \%$ & $18,0 \%$ & $11,1 \%$ & $22,1 \%$ \\
\hline & & $\%$ of Total & $7,4 \%$ & $13,2 \%$ & $1,5 \%$ & $22,1 \%$ \\
\hline & \multirow[t]{4}{*}{ SMA } & Count & 1 & 13 & 1 & 15 \\
\hline & & $\%$ within Pendidikan & $6,7 \%$ & $86,7 \%$ & $6,7 \%$ & $100,0 \%$ \\
\hline & & $\%$ within Persepsi & $11,1 \%$ & $26,0 \%$ & $11,1 \%$ & $22,1 \%$ \\
\hline & & $\%$ of Total & $1,5 \%$ & $19,1 \%$ & $1,5 \%$ & $22,1 \%$ \\
\hline & \multirow[t]{4}{*}{ Diploma } & Count & 0 & 2 & 1 & 3 \\
\hline & & $\%$ within Pendidikan &, $0 \%$ & $66,7 \%$ & $33,3 \%$ & $100,0 \%$ \\
\hline & & $\%$ within Persepsi &, $0 \%$ & $4,0 \%$ & $11,1 \%$ & $4,4 \%$ \\
\hline & & $\%$ of Total &, $0 \%$ & $2,9 \%$ & $1,5 \%$ & $4,4 \%$ \\
\hline & \multirow[t]{4}{*}{ S1 } & Count & 0 & 4 & 1 & 5 \\
\hline & & $\%$ within Pendidikan &, $0 \%$ & $80,0 \%$ & $20,0 \%$ & $100,0 \%$ \\
\hline & & $\%$ within Persepsi &, $0 \%$ & $8,0 \%$ & $11,1 \%$ & $7,4 \%$ \\
\hline & & $\%$ of Total &, $0 \%$ & $5,9 \%$ & $1,5 \%$ & $7,4 \%$ \\
\hline & \multirow[t]{4}{*}{ S2 } & Count & 0 & 1 & 0 & 1 \\
\hline & & $\%$ within Pendidikan &, $0 \%$ & $100,0 \%$ &, $0 \%$ & $100,0 \%$ \\
\hline & & $\%$ within Persepsi &, $0 \%$ & $2,0 \%$ &, $0 \%$ & $1,5 \%$ \\
\hline & & $\%$ of Total &, $0 \%$ & $1,5 \%$ & $.0 \%$ & $1,5 \%$ \\
\hline \multirow{4}{*}{\multicolumn{2}{|c|}{ Total }} & Count & 9 & 50 & 9 & 68 \\
\hline & & $\%$ within Pendidikan & $13,2 \%$ & $73,5 \%$ & $13,2 \%$ & $100,0 \%$ \\
\hline & & $\%$ within Persepsi & $100,0 \%$ & $100,0 \%$ & $100,0 \%$ & $100,0 \%$ \\
\hline & & $\%$ of Total & $13,2 \%$ & $73,5 \%$ & $13,2 \%$ & $100,0 \%$ \\
\hline
\end{tabular}

Tabel 9. Hasil analisis chi-square test hubungan antara persepsi tentang menopause dengan pendidikan

\begin{tabular}{ll}
\hline Hubungan Persepsi-pendidikan & $\mathrm{P}=0,438$ \\
\hline
\end{tabular}

Dari tabel 8. diketahui hubungan persepsi dengan pendidikan yang paling banyak adalah persepsi cukup baik dengan tamatan SD yaitu 18 orang $(26,5 \%)$, kemudian persepsi cukup baik dengan tamatan SMA 13 orang $(19,1 \%)$. Dari hasil analisis dengan uji chi-square di dapatkan $\mathrm{P}=$ $0,438(\mathrm{P}<0,05)$, sehingga dapat dinyatakan tidak ada hubungan antara persepsi dengan pendidikan.

\section{Diskusi}

Tabel 2. menunjukkan dari 68 responden sebanyak 24 orang $(35,3 \%)$ memiliki persepsi cukup baik dengan kecemasan rendah, 16 orang $(23,5 \%)$ memiliki persepsi cukup baik dengan kecemasan sedang, 2 orang $(2,9 \%)$ memiliki persepsi baik dengan kecemasan rendah, 6 orang $(8,8 \%)$ memiliki persepsi baik dengan kecemasan sedang.

Untuk mengetahui nilai signifikansi hubungan antara persepsi tentang menopause dengan kecemasan pada wanita premenopause adalah dengan uji chi-square seperti pada Tabel 3.

Uji chi-square menunjukkan bahwa tidak terdapat hubungan yang signifikan antara persepsi 
tentang menopause dengan kecemasan pada wanita premenopause $(\mathrm{p}>0,05)$.

Tabel 5. menunjukkan ada hubungan yang signifikan antara persepsi tentang menopause terhadap usia $(\mathrm{p}<0,05)$. Hal ini berarti pada usia yang sudah dewasa atau tua, mereka menunjukkan sikap kedewasaannya dan mempunyai pandangan yang positif. Pada orang dewasa yang mempunyai persepsi baik dikarenakan adanya kultur sosial yang baik dan gaya hidup yang masih tradisional atau rural. Sedangkan persepsi yang tidak cukup baik dikarenakan oleh gaya hidup urban dan telah menghilangkan nilai tradisional (Macia et al., 2009).Hubungan kecemasan dengan usia dewasa atau tua juga berkaitan dan ini ditemukan pada wanita premenopause dan wanita yang mendapat Hormon Replacement Terapy (HRT) serta wanita yang sudah menopause (Eum et al. 2012).

Dilihat dari tabel 7. persepsi berhubungan dengan pekerjaan. Ini menunjukkan bahwa proses persepsi saatbekerja baik. Saat pekerjaan seseorang sudah lama atau berpengalaman, seseorang akan cenderung meginterpretasikan stimulus persepsi itu dengan baik. Pekerjaan juga berkaitan dengan kecemasan. Seseorang akan merasa cemas apabila pekerjaannya sulit. Sebuah penelitian menemukan bahwa suatu pekerjaan seperti menjadi polisi akan membuat stress dan cemas terutama pada wanita. Karena pekerjaan ini dianggap berbahaya dan sering terkena berbagai situasi yang traumatis mulai dari ancaman untuk diri sendiri dan rekanrekannya (Husain et al., 2014).

Pada tabel 9. menunjukkan bahwa tidak ada hubungan antara persepsi dengan pendidikan. Walaupun dalam hal pengetahuan sangat berhubungan dengan persepsi, tetapi pendidikan yang tinggi belum tentu membuat seseorang memiliki pengetahuan yang luas. Pendidikan dengan kecemasan bisa terjadi pada tenaga medis dan mahasiswa kedokteran yang mengalami stres dan kecemasan. Faktor stres dan kecemasan yang paling tinggi adalah ketika akan menghadapi ujian dan menganggap tanggung jawab untuk menjadi seorang dokter sangat besar, serta mereka hanya mempunyai sedikit waktu luang untuk urusan pribadi (Duica et al., 2012). Masalah sosial ekonomi juga sangat berpengaruh. Orang tua yang kesulitan finansial akan merasa cemas memikirkan apakah anaknya akan bisa menempuh pendidikan lebih lanjut, dapat memenuhi kebutuhan seharihari dan bahkan mereka yang mengalami kesulitan finansial merasa bahwa kondisi ekonominya tidak akan naik di kedepannya. Kecemasan ini akan menimbulkan dampak pada fisik mereka seperti tidak bisa tidur malam, mood yang berubah-ubah, peningkatan nafsu makan dan cenderung memakai alkohol untuk bisa menenangkan kecemasannya (callan \& Howland, 2009).

Menurut Mulyani (2013), faktor lingkungan sekitar tempat tinggal dapat mempengaruhi cara berpikir seseorang, baik tentang dirinya atau orang lain. Kecemasan akan timbul jika seseorang merasa tidak aman terhadap lingkungannya. Selain itu pengaruh dukungan keluarga sangat penting bagi seseorang yang akan masuk ke fase menopause. Karena kondisi ini sangat membuat kekhawatiran sehingga di perlukan pengertian dari suami dan juga anak-anak sebagai anggota keluarga terdekat. Pada saat itu wanita membutuhkan pengertian atas ketidakstabilan emosi yang di alami dengan dukungan positif.

Tidak adanya hubungan yang bermakna antara kedua variabel di sebabkan di Desa Brajan Kecamatan Kasihan Kabupaten Bantul ini di pengaruhi oleh faktor-faktor lain yang tidak di teliti pada penelitian ini. Faktor-faktor lain yang dapat mempengaruhi kecemasan di antaranya adalah faktor lingkungan, sosial ekonomi, umur dan pekerjaan.

\section{Simpulan}

Hasil penelitian ini dapatdisimpulkan sebagai berikut:

1. Hasil penelitian menunjukkan bahwa tidak ada hubungan antara persepsi tentang menopause dengan kecemasan pada wanita premenopause dengan nilai $\mathrm{p}=0,269$.

2. Usia berhubungan dengan persepsi. Hal ini ditunjukkan adanya hubungan yang signifikan antara usia dengan persepsi $(\mathrm{P}=0,002)$.

3. Pekerjaan berhubungan dengan persepsi. Hal ini ditunjukkan adanya hubungan yang signifikan antara pekerjaan dengan persepsi $(\mathrm{P}=0,017)$.

4. Pendidikan tidak berhubungan dengan persepsi. Hal ini ditunjukkan tidak adanya hubungan yang signifikan antara pendidikan dengan persepsi $(\mathrm{P}=0,438)$.

5. Tidak adanya hubungan yang signifikan antara persepsi dengan kecemasan 
dikarenakan adanya faktor-faktor lain yang memepegaruhi seperti usia, pekerjaan, pengalaman, sosial ekonomi, lingkungan dan lain-lain.

\section{Saran}

Dari penelitian di atas, disarankan penelitian lebih lanjut menggunakan variabel usia dan pekerjaan yang terkait dengan premenopause. Dan bukan hanya dilihat dari kualitatif saja, tetapi dari segi kuantitatif juga harus diperhatikan. Peneliti selanjutnya bisa membuat wawancara atau focus grup discussion agar membuat responden menjadi tahu dan mendapat ilmu.

\section{Daftar Pustaka}

Callan, J.A., \& Howland, R.H. (2009). Economic anxiety. Journal of psychosocial nursing. 3, 47.

Duica, L., Talau, R., Nicoara, D., Dinca, L., Turcu, J., Talau, G., 2012. Stress-anxiety-coping triad in medical students, Journal of medical science \& psychology. 2, 96-104.

Eum, K.D.,Korrick, S.A., Weuve, J., Okereke, O., Kubznsky, L.D., Howard, H., et al., 2012.
Relation of cumulative low-level lead exposure to depressive and pobic anxiety symptom scores in middle age and elderly women. Enviromental health perspectives. 6,817

Guyton, A.C., \& Hall, J.E., 2008. Buku ajar fisiologi kedokteran $\left(11^{\text {th }}\right.$ ed). Jakarta: EGC.

Husain, W., Sajad, R., \& Rehman, A., 2014. Depression, Anxiety and stress among female and male police officers. Pakistan Journal of clinical psychology, 13, 3-14.

Macia, E., Lahman, A., Abdelatif, B., Boetsch, G., et al., 2009. Perception of age stereotypes and self perception of aging: A comparison of french and moroccan populations, springer science. 24, 391-410.

Mulyani, S.N., 2013. Menopause : Akhir siklus menstruasi pada wanita di usia pertengahan . Yogyakarta: Nuha Medika.

Proverawati, A. (2010). Menopause dan Sindrom Premenopause. Yogyakarta: Nuha Medika.

Singh, M., \& Singh, G. (2006). A comparison of mental health status during menopause and post-menopause middle-aged worked women. Internet Scientific Publications., Diakses 1 April 2014, dari http://ispub.com/ IJWH/4/1/4561 